Historic, Archive Document

Do not assume content reflects current scientific knowledge, policies, or practices. 



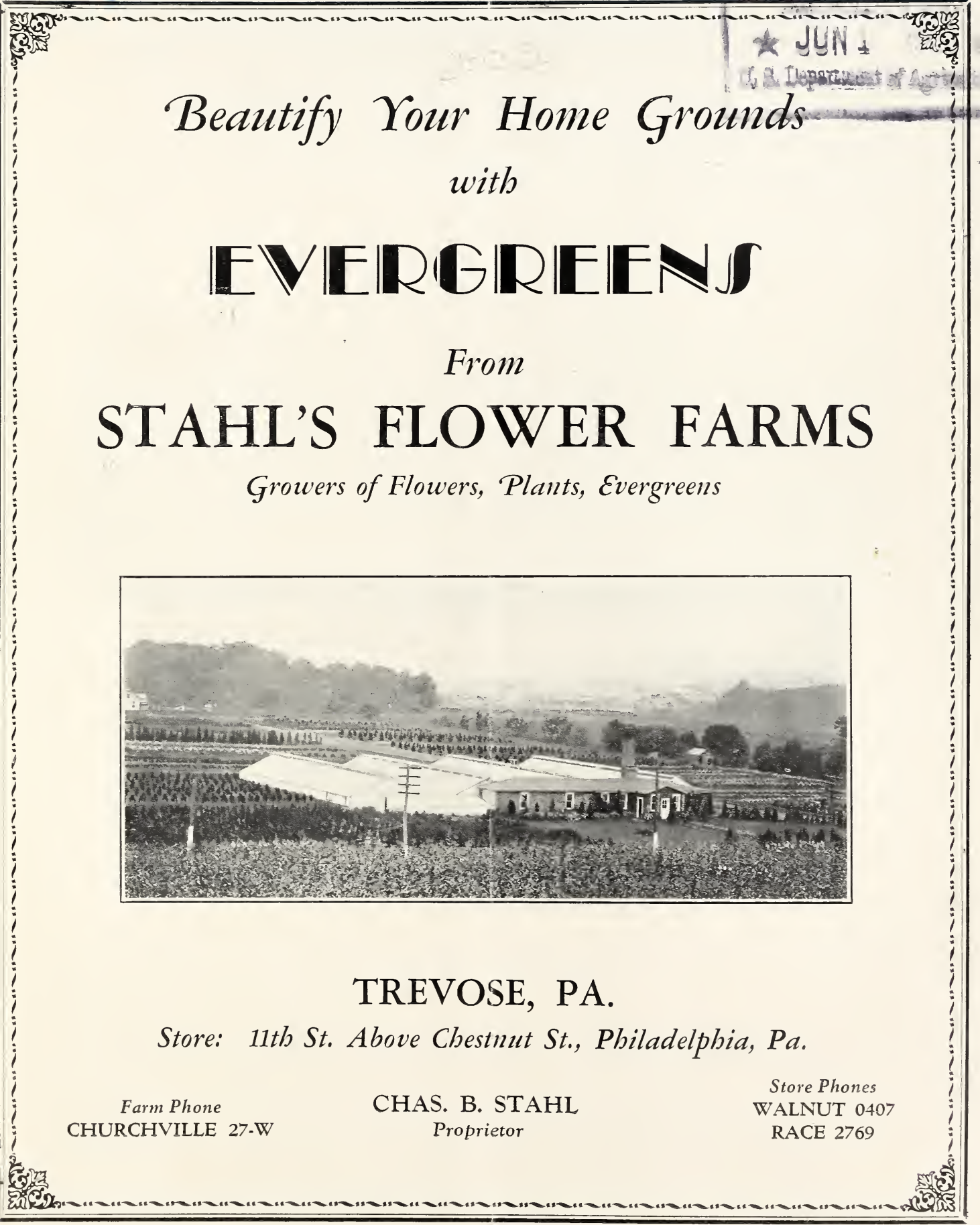




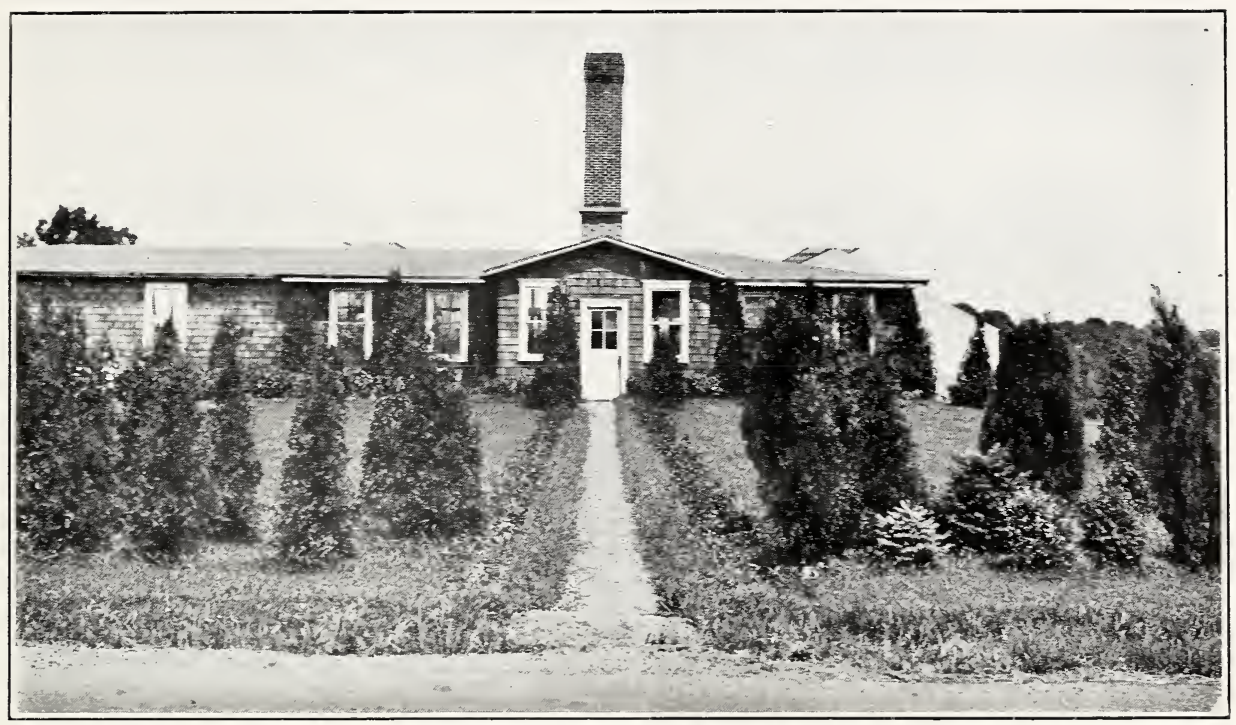

Our Office and Service Building at Trevose, $P a$.

UR Flower Farm is located on Street Road, Trevose, twenty miles from City Hall, Philadelphia. Take train to Trevose on Reading Railroad. By bus take Frankford train in Market Street subway to Margaret Street, take Trenton or Langhorne bus to Street Road, Trevose, walk north one-quarter mile to farm. By automcbile take Roosevelt Boulevard to City Line, continue on Lincoln Highway to Street Road, turn north to farm.

If not convenient to visit our farm, selection of evergreens can be made at our store or we send our representative to your home and are always glad to offer sug, gestions and submit estimates.

Our evergreens are of the best quality, carefully dug with large ball of earth and burlap wrapped.

$$
\text { FLOWER FARM-TREVOSE, PA. }
$$




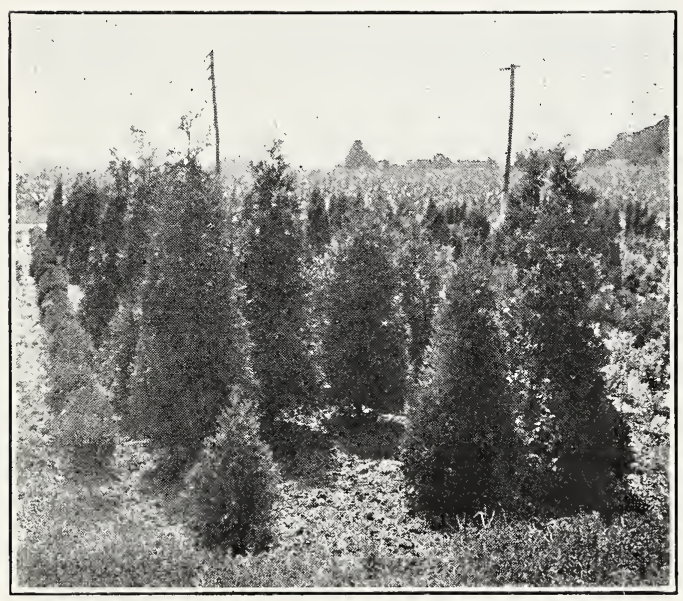

\section{THUYA OCCIDENTALIS}

\section{American Arborvitea}

Pyramidal in form, very hardy in al most any situation, rapid grower. One of the most dependable evergreens.

12 to 15 inches............\$1.00

15 to 18 inches.............. 1.50

18 to 24 inches............. 2.00

2 to 3 feet................ 3.00

3 to 4 feet............... 4.00

4 to 5 feet.......... 5.00 and 6.00

5 to 6 feet............... 7.50

6 to 7 feet............... 10.00

7 to 8 feet........ 12.00 and 15.00

Specimen Trees ........... 25.00

\section{THUYA GLOBOSA}

Globe Arborvitea

Good green color, globe in form, very hardy.

12 to 15 inches................\$1.50

15 to 18 inches................... 2.00

18 to 24 inches...................... 2.50

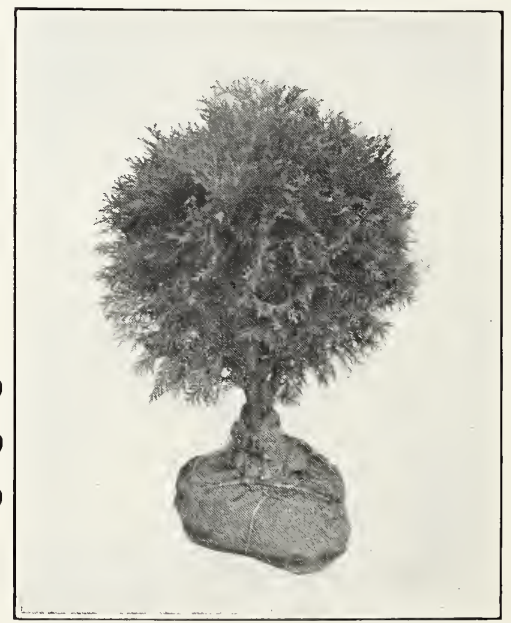

STORE, ELEVENTH ST. ABOVE CHESTNUT, PHILA. 


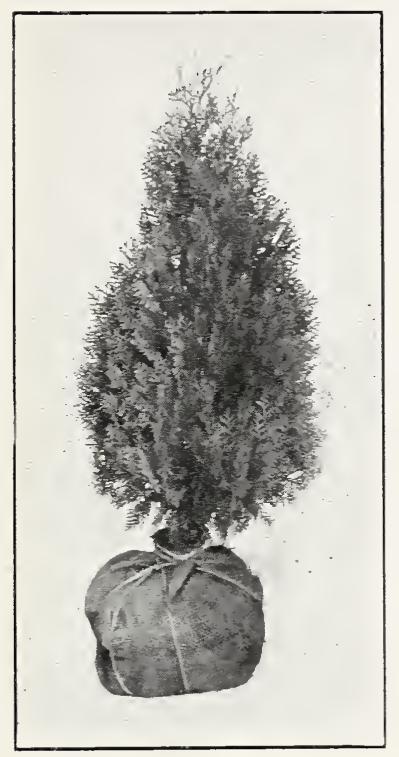

\section{THUYA ORIENTALIS}

\section{Chinese Arborvitea}

Strictly pyramidal habit; growth, dense and quick; bright green foliage.

12 to 15 inches......................... $\$ 1.00$

15 to 18 inches......................... 1.50

18 to 24 inches......................... 2.00

2 to 3 feet................................... 3.00

3 to 4 feet............................ 4.00

+ to 5 feet............................. 5.00

\section{THUYA ORIENTALIS COMPACTA}

\section{(Biotas)}

Straight symmetrical grower. Very desirable plant.

12 to 15 inches..................... \$1.00

15 to 18 inches........................... 1.50

18 to 24 inches...................... 2.00

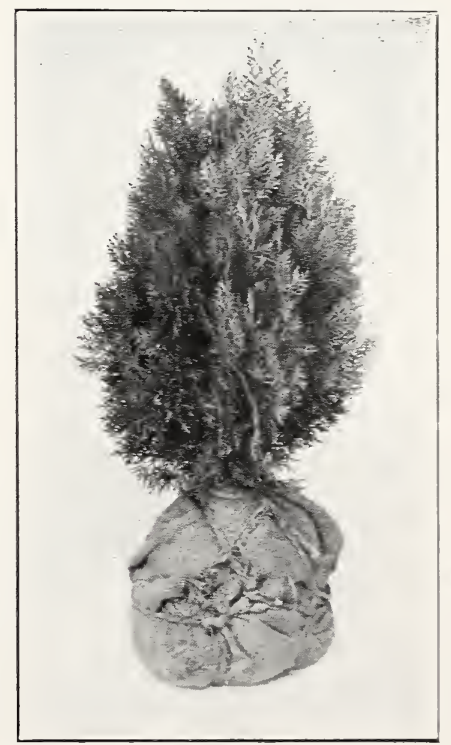




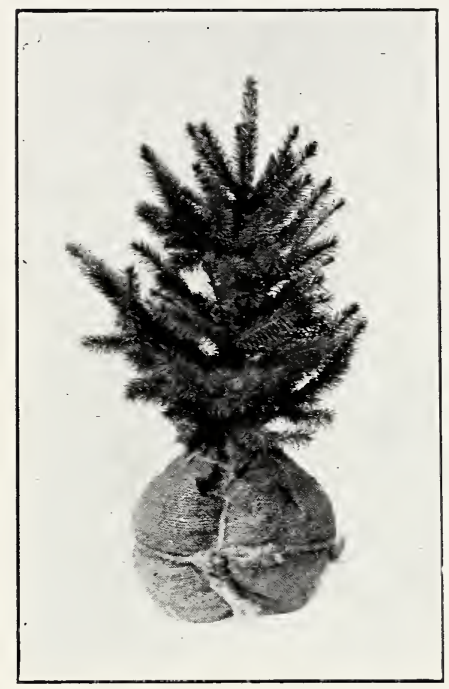

\section{PICEA CANADENSIS}

\section{White Spruce}

Popular variety. A compact, upright grower.

Pyramidal in form. Very hardy.

12 to 15 inches........................ $\$ 1.00$

15 to 18 inches...................... 1.50

\section{PICEA EXCELSA}

\section{Norway Spruce}

Hardy, quick growing tree, graceful in all its lines. Adapted to most any condition.

12 to 15 inches.............\$1.00

$11 / 2$ to 2 feet............ 2.00 to 2.50

2 to 3 feet............... 3.00

3 to 4 feet................. 4.00

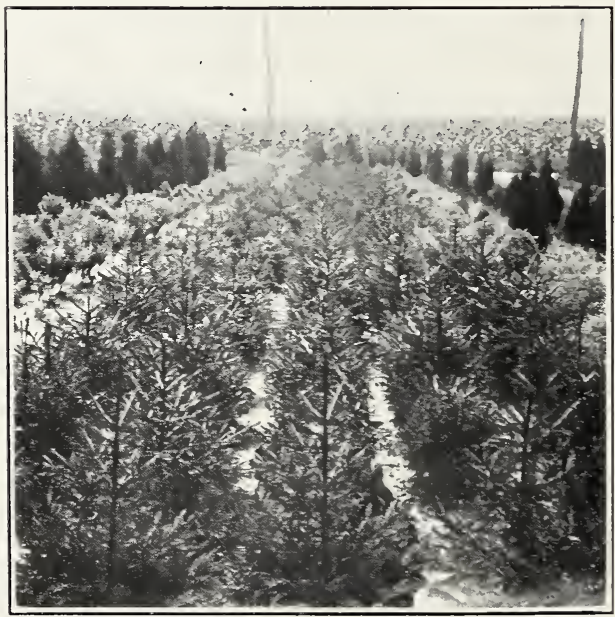

STORE, ELEVENTH ST. ABOVE CHESTNUT, PHILA. 


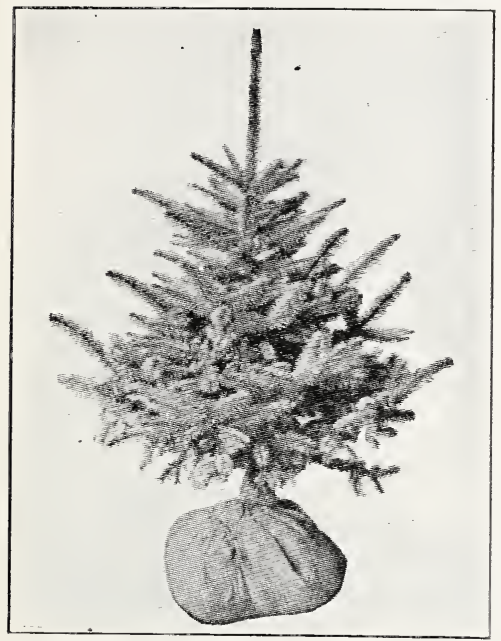

\section{PICEA PUNGENS}

Colorado Blue Spruce

12 inches ...................\$1.50 each

$11 / 2$ to 2 feet...................... 5.00 each

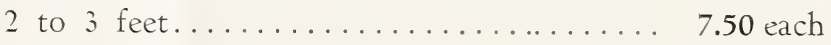

3 to + feet.......................... 10.00 each

+ to $j$ feet........................... 15.00 each

\section{HYDRANGEA-PANICULATA GRANDIFLORA}

Blooms July to September. Pear-shaped flower. White, turning pink to bronze.

2 to 3 feet.................\$ \$1.00 each

3 to + feet.................... 1.50 each
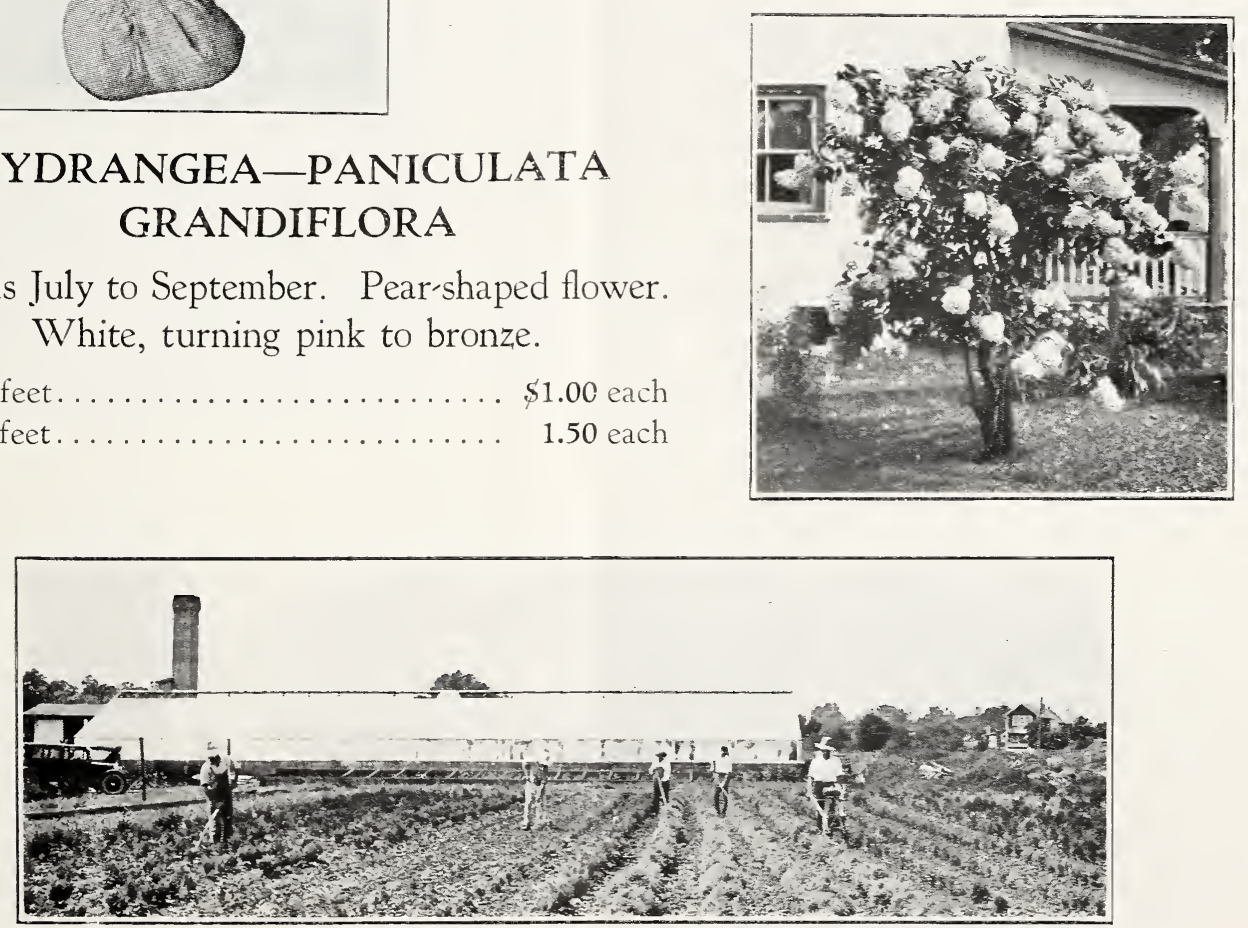

One of Our Fields of Small Evergreens Being Constantly Cultivated to Encuorage Root Action and Vigorotis Growth

FLOWER FARM-TREVOSE, PA. 
STAHL'S EVERGREENS-FLOWERS-PLANTS

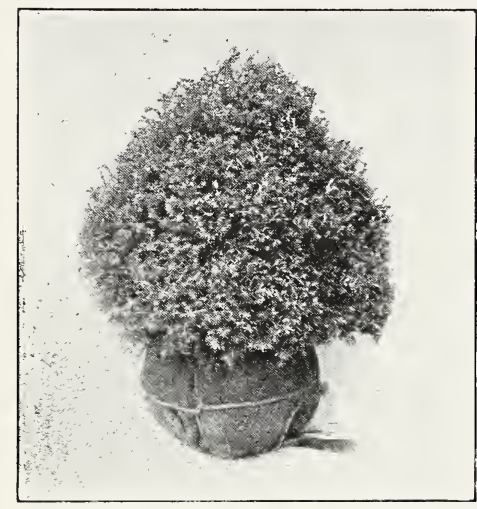

\section{RETINSPORA SQUARROSA VEITCHI Silver Japanese Cypress}
A most ornamental, graceful evergreen. Foliage blue green.

10 to 12 inches................... \$1.00

12 to 15 inches...................... 1.50

15 to 18 inches...................... 2.00

18 to 24 inches...................... 3.00

2 to 3 feet........................ 4.00

\section{RETINSPORA PLUMOSA AUREA} Golden Plumed Cypress

Semi-dwarf, yellow tips, compact grower.

10 to 12 inches..................\$1.00

12 to 15 inches................... 1.50

15 to 18 inches...................... 2.50

18 to 24 inches................... 3.50

2 to 3 feet...................... 5.00

3 to 4 feet...................... 6.00
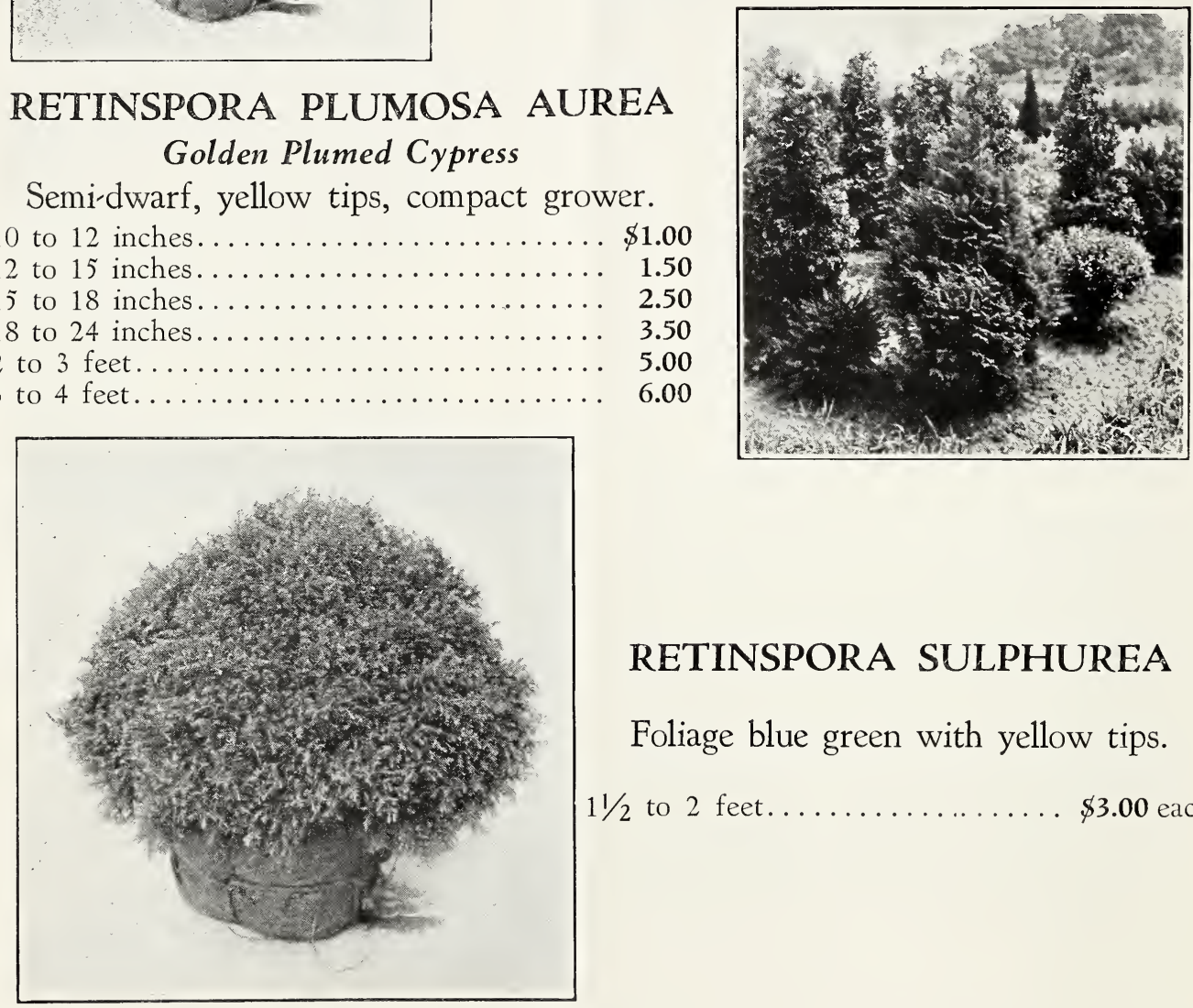

\section{RETINSPORA SULPHUREA}

Foliage blue green with yellow tips.

$11 / 2$ to 2 feet............. \$3.00 each

STORE, ELEVENTH ST. ABOVE CHESTNUT, PHILA. 


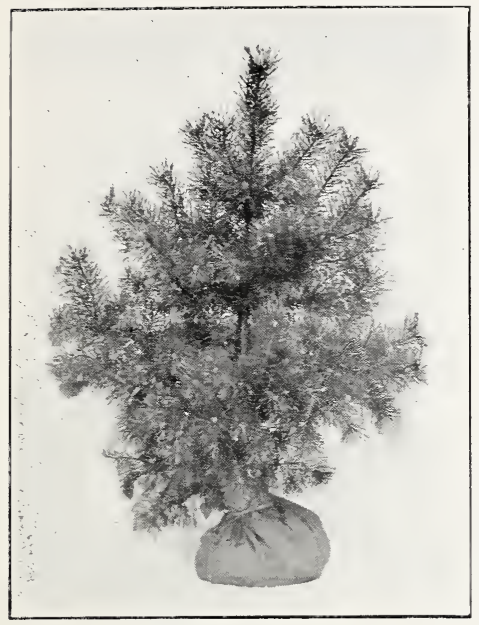

\section{PINUS SYLVESTRIS}

\section{Scotch Pine}

It is valuable for its rapidity in growth and great hardiness.

1 to 2 feet.................. \$2.00 each

2 to 3 feet.................... 3.00 each

3 to 4 feet................. 4.00 each

\section{GOLDEN PRIVET}

Hardy, desirable plant for individual or hedge planting. Quick grower. Can be sheared to any shape.

Bush Form-

10 to 12 inches..........\$0.50 each

12 to 15 inches........... 1.00 each

15 to 18 inches........... 1.50 each

Globe and Pyramidal Form-

12 to 15 inches........... 1.00 each

15 to 18 inches........... 1.50 each

18 to 24 inches........... 2.00 each

24 to 36 inches........... 3.00 each

Standard Form-

12-inch stem, 8-inch diameter of head ............... 1.00 each

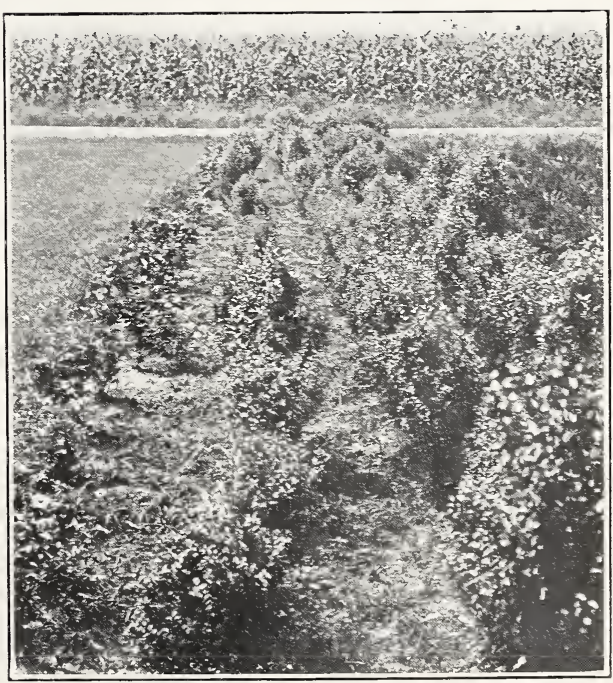

FLOWER FARM- TREVOSE, PA. 


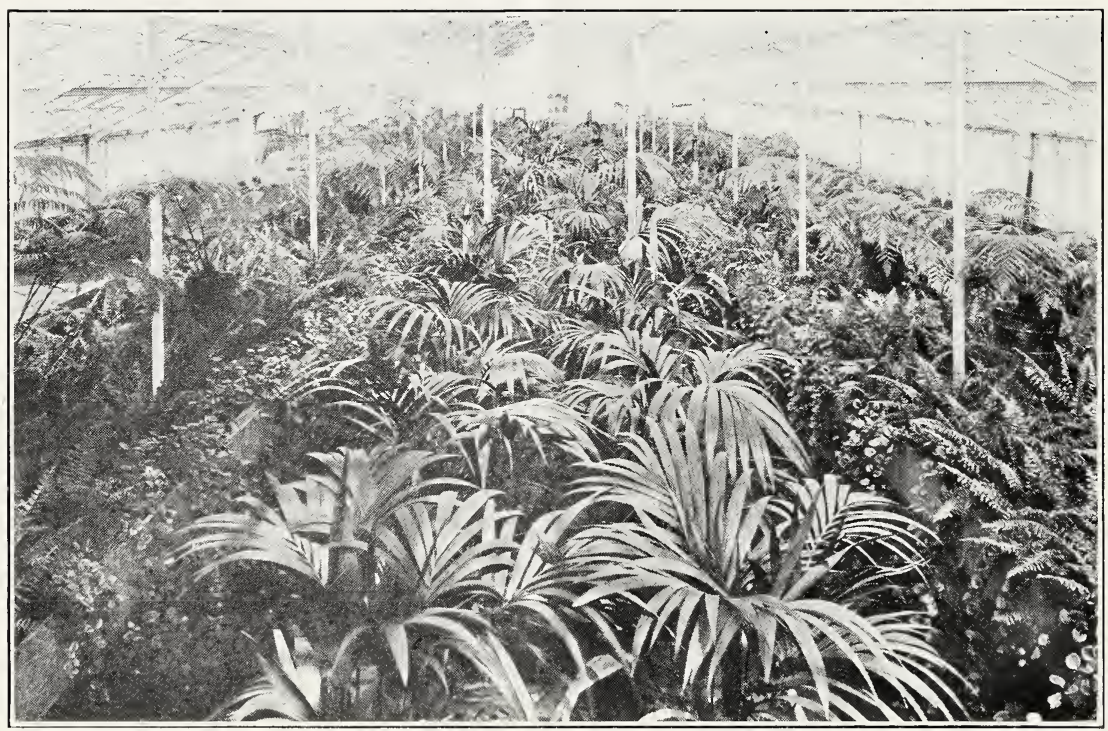

A view of one of our greenhouses, which are always stocked with palms. All foliage and blooming plants in season. Consult us as to what plants are suitable for house, porch or conservatory.

Boston Ferns in all sizes at reasonable prices.

Floral Decorations for Weddings and designs for all occasions.

All inquiries as to flowers and plants are cheerfully answered and estimates furnished.

Our cut flowers keep better because they are cut fresh from our greenhouses each day.

52 Years Service as Everybody's Florist

STORE, ELEVENTH ST. ABOVE CHEST NUT, PHILA. 



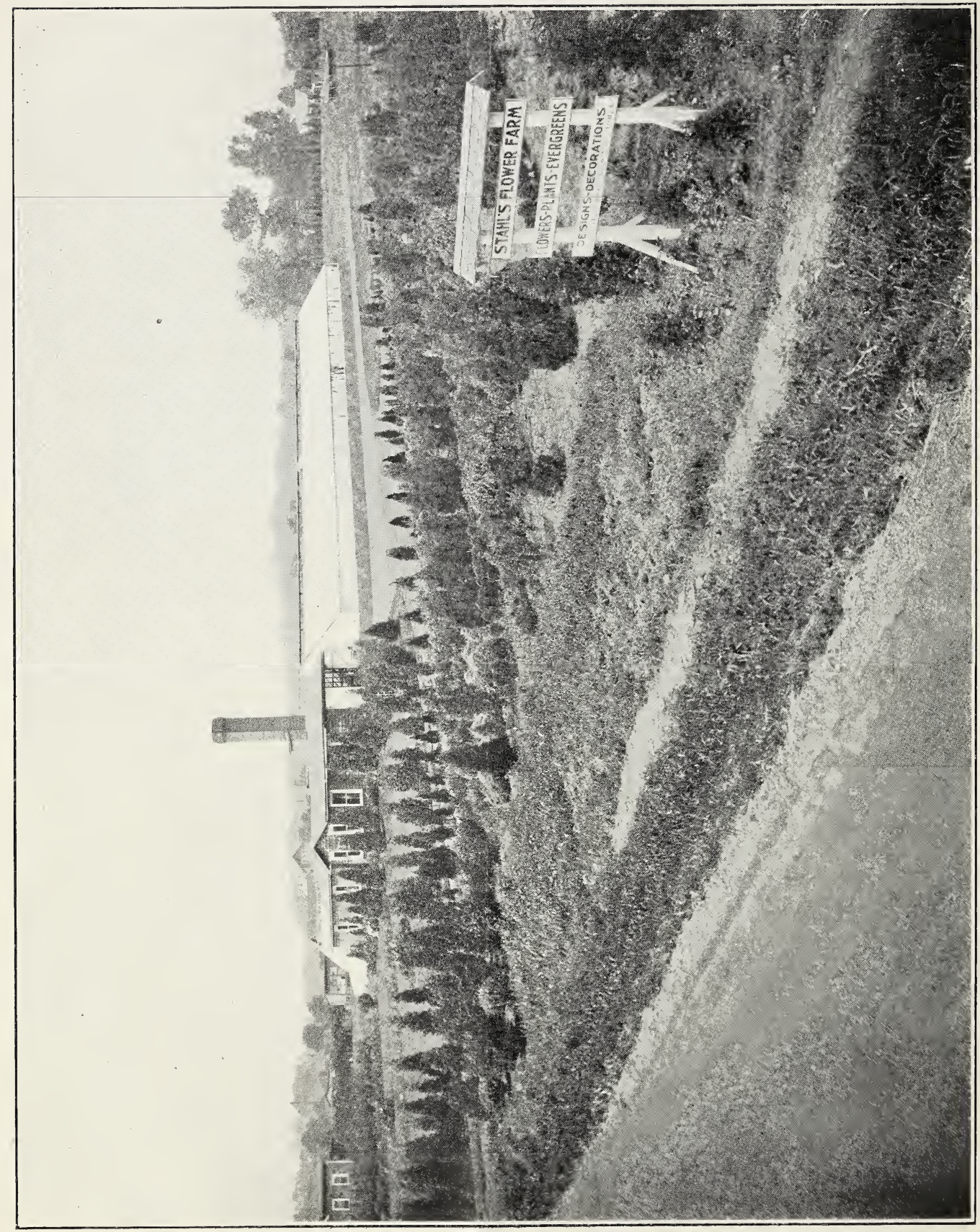

